$10-2017$

\title{
Book Review: Representing Genocide: The Holocaust as Paradigm?
}

Emily Sample

Holocaust Museum Houston

Follow this and additional works at: https://digitalcommons.usf.edu/gsp

\section{Recommended Citation}

Sample, Emily (2017) "Book Review: Representing Genocide: The Holocaust as Paradigm?", Genocide Studies and Prevention: An International Journal: Vol. 11: Iss. 2: 112-113.

DOI:

http://doi.org/10.5038/1911-9933.11.2.1483

Available at: https://digitalcommons.usf.edu/gsp/vol11/iss2/12

This Book Review is brought to you for free and open access by the Open Access Journals at Digital Commons @ University of South Florida. It has been accepted for inclusion in Genocide Studies and Prevention: An International Journal by an authorized editor of Digital Commons @ University of South Florida. For more information, please contact digitalcommons@usf.edu. 
Book Review: Representing Genocide: The Holocaust as Paradigm?

\author{
Emily Sample \\ Holocaust Museum Houston \\ Houston, Texas, USA
}

Representing Genocide: The Holocaust as Paradigm?

Rebecca Jinks

London, Bloomsbury, 2016

269 Pages; Price: \$114.00 Cloth

Reviewed by Emily Sample

Holocaust Museum Houston

Rebecca Jinks' Representing Genocide: The Holocaust as Paradigm? endeavors to grow the conversation about Holocaust representation to include other genocides, and to understand the innate relationship these representations have to one another. Her analysis hinges upon her nonchronological approach to understanding how other genocides have been understood in the public domain, namely the cases of Armenia, Rwanda, Cambodia, and the former Yugoslavia. She intentionally chooses to engage with the five most prominently represented and understood genocides by Western audiences. She examines how these five genocides, the Holocaust chief among them, have been represented in various ways in what she calls Western culture. Jinks considers five major themes: recognizing genocide, explaining genocides, witnessing genocide, resolving genocide, and responding to genocide. The focus throughout the book is clearly and specifically on these four non-Holocaust genocides, and how they connect with and have been influenced by the canonization of the Holocaust in Western memory. She does not delve deeply in the debates around Holocaust memory-though she acknowledges them-but rather focuses on how those scholarly debates have or have not seeped into the public purview, and how they have influenced the representations of other genocides. Similarly, she states she would not be analyzing these representations with a gendered lens, but goes on to rightly explain that the representations of genocide by and against men, women, and children--both girls and boys-should be responsive to those experiences. She critiques a broad spectrum of types of representation including film, books, museum exhibitions and memorials, as well as photographs and art, in an effort to make connections across "otherwise fairly isolated literatures." ${ }^{1}$

The first chapter focuses on how the Western cultural memory understands what genocide is by measuring events against the most widely understood and acknowledged genocide in the public sphere: the Holocaust. By intermingling analysis of scholarly works with fictional or semifictional public history, Jinks creates what she calls 'genocidal imaginary,' a "free-floating, abstract cultural conception of 'what genocide is,' and how it happens." 2 She cautions that this idea can be different for every person within a collective and that it is ever changing based on the current cultural zeitgeist. Despite this ever-shifting concept, the chapter continues on to describe how the public recognizes the script of genocide in different representations, based on this imaginary ideal and the stereotypical depictions of helpless victims, morally unambiguous perpetrators, and an un-Earthly setting. This chapter concludes with credit to A. Dirk Moses, Scott Straus, and Robert Lyons, among others, for their contribution to breaking down this 'genocidal imaginary' in their works.

In chapter two, Jinks examines the construction of the genocidal narrative around perpetrators and the causes of genocide. Jinks argues that genocide and its perpetrators are portrayed as deviants from the norm, with domestic origins divorced from international or historical context. For the only time in this work, Jinks disconnects the cases of Armenia, Cambodia, Rwanda, and Bosnia

\footnotetext{
${ }^{1}$ Rebecca Jinks, Representing Genocide: The Holocaust as Paradigm? (London: Bloomsbury, 2016), 21.

${ }^{2}$ Ibid., 29.
} 
to highlight different mediums of representation. She concludes that mainstream narratives in all four cases follow the pattern set by Holocaust representation, presenting genocide as a unique event with little or no action by the West taken for understanding, ending, or preventing genocide.

Jinks follows this argument in chapter three by examining the role of the Westerner in representations of genocide. While it is unclear where the line for Westerner begins in reference to the genocides in Europe, it is assumed Germans after the Holocaust are included in this definition, but not before. She focuses this chapter on not only Western bystanders and eyewitnesses to genocides, but on their role in storytelling to Western audiences and their predisposition to reference the Holocaust for comparison. Unlike the Holocaust, though, Jinks argues that in mainstream representations of other genocides the voice of the Western outsider is more prominent than victim's voices.

Chapter four highlights two major debates in genocide scholarship: post-genocidal justice and remembrance. While being highly critical, Jinks steers clear of typical hot button arguments, honing in instead on how these scholarly debates, i.e. the effectiveness of criminal tribunals, are represented and supported. She clearly depicts her feelings on the issue without clouding the subject at hand-how these representations reflect and even manipulate popular opinions of these cases in Western cultural context. Jinks highlights the representations of resolution, justice, and a return to pre-genocide normalcy as "comforting and problematic." 3 She argues this false sense of closure fails to accurately portray the challenges and realities post-genocide societies continue to face and is constructed for Western convenience.

In her final chapter, Jinks extends this critique to Western responses to genocide. The representations discussed in the previous four chapters allow mainstream audiences to distance themselves from genocide, to understand it as an aberrant, inevitable event. This failure, Jinks argues, allows Westerners and their leaders to claim understanding of past genocides without investigating the true causes. Here she returns to how representations of the Holocaust elicit emotional, rather than inquisitive responses, and how this has determined the simplified style of representation for other genocides to Western audiences. She points to a minority of narratives that challenge this idea by encouraging complex critical thinking about choices, roles, and context during genocide.

Jinks assumes a fair amount of knowledge of not only the histories of each of these cases, but the representations of each case she discusses. There is little or no introduction to the pieces she discusses, making this a book well suited for those familiar with these cases and their place in Western canon. General awareness and understanding of representations of the Holocaust are implied, and are not unnecessarily analyzed. In this way, the question the title asks, Holocaust as Paradigm?, is rather discussed as a statement, as there is no other event or comparison that could be made in this analysis. Her strength is in connecting these cases in new ways, namely thematically, instead of measuring each to representations of the Holocaust in a vacuum.

While her stated goal for the book is to understand representations of genocide, she is critical throughout of these representations lacking content or context. She repeatedly hones in on specific pieces that do not, she argues, add to the conversation about how or why genocide happens, but rather focus "on the atrocities and their outcomes, less the cases and process." ${ }^{4}$ The underlying argument is that genocide representations that do not include or encourage deeper scholarship do not assist in the mission of understanding genocide or its prevention, despite their purported goal of raising awareness.

Overall, Representing Genocide: The Holocaust as Paradigm? encourages greater complexity in genocide representation and encourages readers to seek out and promote narratives that problematize the current status quo.

\footnotetext{
${ }^{3}$ Ibid., 184.

${ }^{4}$ Ibid., 65 .
} 